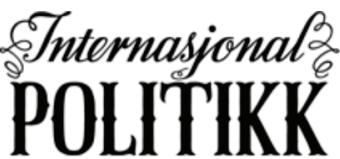

SKANDINAVISK TIDSSKRIFT

FOR INTERNASIONALE STUDIER

Årgang 79, Nummer 3, side 257-260, 2021, ISSN 1891-1757, www.tidsskriftet-ip.no, Publisert august 2021

\section{Hva er Internasjonal Politikk}

\author{
Tora Sagård \\ Peace Research Institute Oslo (PRIO)
}

Hva er Internasjonal Politikk, skrevet av Benjamin de Carvalho og Halvard Leira, handler om hvordan man kan nærme seg internasjonal politikk på systematiske måter og hvordan ulike hendelser kan forstås i sammenheng. Kort fortalt handler boken om faget Internasjonal Politikk.

Boken, som er på omtrent 140 sider, rommer i tillegg til introduksjon og konklusjon fire kapitler med ulike tema: grenser for internasjonal politikk i tid og rom, teorier om internasjonal politikk, tema og emner i internasjonal politikk og faget Internasjonal Politikk. Boken tar dermed for seg viktige aspekter for å forstå hva internasjonal politikk er.

Med en mastergrad i statsvitenskap med fordypning i internasjonal politikk skulle man tro jeg ikke har så mye å få ut av en «hva er»-bok. Etter fem år med studier har man vel lært og forstått hva internasjonal politikk er? Svaret er at dette er en bok som passer til alle, uavhengig av forkunnskap. Selv om jeg på forhånd hadde kjennskap til hovedteoriene innen faget, og gjennom ulike fag hadde en ide om hva faget gikk ut på, har det for meg, som for mange andre, vært knyttet usikkerhet til hva internasjonal politikk (IP) egentlig er. Er internasjonal politikk alt utenfor et lands egne grenser? Og hva skiller egentlig IP fra andre nærliggende disipliner som International Relations eller global politikk? Eller er det egentlig det samme?

Hva er Internasjonal Politikk er en lettleselig bok som guider leseren gjennom hovedtrekkene for å forstå nettopp hva IP er. Boken søker å gi en innføring i hva som er de viktigste temaene, perspektivene, teoriene og debattene innenfor IP-faget. Selv om boken på mange måter inneholder de samme temaene som andre lærebøker om IP, skiller den seg ut ved at de ikke forsøker å forklare hva «riktig» IP er. Snarere forsøker forfatterne å gi leseren de riktige verktøyene og metodene for selv å danne

(C2021 Tora Sagård. This is an Open Access article distributed under the terms of the Creative Commons Attribution 4.0 International License (http://creativecommons.org/licenses/by/4.0/), allowing third parties to copy and redistribute the material in any medium or format and to remix, transform, and build upon the material for any purpose, even commercially, provided the original work is properly cited and states its license.

Citation: Sagärd, T. (2021). Hva er Internasjonal Politikk. Internasjonal Politikk, 79(3), 257-260. http://dx.doi.org/10.23865/ intpol.v79.3124 
seg en egen mening. For å gi leseren de riktige verktøyene viser de hvordan teori og hendelser henger sammen, og hvordan ulike teoretiske antagelser kan belyse ulike begivenheter på nye måter. Dette er en bok om forståelse, ikke fakta, som forfatterne så fint sier. Og er det en ting de får til, så er det å formidle på en måte som skaper nettopp forståelse. Carvalho og Leira bruker gjennom hele boken ulike eksempler for at leseren skal henge med, alt fra klimautfordringer, brexit, relasjonen mellom USA og Kina, samt koronapandemien. Måten de bruker eksempler og kontekstualiserer ulike begreper giør at selv lesere med lite forkunnskaper raskt vil kunne sette seg inn i og forstå hva det snakkes om. Og selv om dette er hele grunntanken bak en «hva er»-bokserie, er det ikke gitt at man klarer å formidle dette på en god måte.

Noe jeg savnet da jeg studerte var det kritiske aspektet ved hvor kunnskapen man studerer kommer fra. Her er Carvalho og Leira gode. Tidlig i boken trekker de frem hvordan faget IP er sterkt preget av at det har blitt utviklet i Vesten, med fokus på Vestens historie og problemer. Dette er gjentagende gjennom hele boken, og de passer på at dette er noe leseren tenker på underveis. Spesielt i kapittelet hvor de diskuterer teoriretninger innenfor IP-faget er dette noe som tillegges stor vekt. De trekker for eksempel frem at et fellestrekk for flere av de første teoriene var et ønske om å sikre Vestens rolle i verden, og at IP-faget som en konsekvens har «oversett eller omskrevet andre historier enn de som passet inn i hovedfortellingen om faget» (s. 80). Dette har også gjort at flere innføringsbøker til faget IP den dag i dag kun fokuserer på nettopp denne «hovedfortellingen".

Carvalho og Leira følger sporene til tradisjonelle introduksjonsbøker ved at de vier stor plass til de tre hovedteoriene i IP, og bruker teorikapittelet til å introdusere de tre hovedretningene innen faget: realismen, liberalismen og konstruktivismen. De diskuterer ikke bare hva de går ut på, men går også inn på at man må være klar over de historiske røttene til de ulike teoriene, og at vår forståelse av teoriene har endret seg over tid. De trekker for eksempel frem at selv Woodrow Wilson, som av mange er regnet som en liberal tenker, åpenbart var rasist.

De trekker også frem at valg av teori er med på å farge hvordan begreper man bruker. Som Carvalho og Leira selv skriver: «begreper har som regel mye historisk bagasje. Å være klar over den bagasjen er en forutsetning for å kunne bruke disse begrepene på en fornuftig måte» (s. 20). De trekker frem feministisk teori, som fokuserer på hvordan sentrale begreper i fag og praksis er grunnleggende «kjønnet» - «at menn konstrueres som krigere og kvinner som omsorgspersoner, og at statsledere avbildes med bar overkropp på hesteryggen og for all del ikke må fremstå som myke og med svake håndtrykk» (s. 81). Kvinner, allerede $\mathrm{i}$ årene under og etter første verdenskrig, trakk på feministisk tenkning for å forstå sammenhengen mellom for eksempel manglende likestilling internt $i$ land og utfordringer i internasjonal politikk. Likevel var denne teoretiseringen ifølge forfatterne fullstendig ignorert frem til 1980-tallet. Til tross for at feministisk teori har fått en større og viktigere plass i dag, er vi fortsatt ikke helt i mål med å viske ut det kjønnede språket. Dette er viktig å ha $\mathrm{i}$ bakhodet når man skal bruke ulike teorier eller begreper, eller når man selv leser 
faglitteratur. Sannelig, dette er noe jeg, selv etter fem år med studier, og en jobb på et fredforskningsinstitutt (PRIO), må minne meg selv på - hvor viktig det er å være klar over konnotasjonene som henger i ulike begreper, alt ettersom hvem og hvor de ble dannet.

Samtidig vier de også tid til å snakke om hvorfor vi trenger teorier. Hvordan teorier skal hjelpe oss å forstå de mest sannsynlige sammenhengene, hendelsene eller handlingene, og at vi trenger teorier for å forstå hvordan samfunnet henger sammen. De ønsker å vise leseren hvilken bredde av forståelser og antagelser som finnes, og hvordan ulike teoretiske antagelser kan belyse ulike hendelser på nye måter. De gir således ikke bare en god innføring i de ulike teoretiske hovedretningene, men også en viktig påminnelse om at hvilke teorier man velger også vil være med å påvirke hvordan vi ser og oppfatter verden. "Teorier er alltid for noe og for noen", så det at vi forstår verden på en måte, gjennom den teoretiske linsen vi har valgt, betyr ikke nødvendigvis at dette er eneste måten å forklare et gitt fenomen. Tvert imot passer forfatterne på å gjøre leseren bevisst på at selv om gitte fenomener tidligere har blitt forklart gjennom en spesifikk teori, betyr ikke dette at det er den eneste riktige måten å forklare det på, eller at det i det hele tatt er riktig linse å se det gjennom. Et eksempel de bruker på hvordan teorier kan benyttes til å opplyse ulike aspekter ved en hendelse, er studier av årsaker til andre verdenskrig. Rett etter krigen var det vanlig å legge mye vekt på personen Adolf Hitler. Senere har forskere derimot vektlagt større samfunnsmessige faktorer, som for eksempel den strenge fredstraktaten i Versailles, europeisk antisemittisme og manglende demokratisk kultur i Tyskland. Dette viser at ikke bare er verden i stadig forandring, men det er også hvordan vi ser og oppfatter den. Dette er noe man må huske på og ta stilling til når man søker å forstå hvordan samfunnet henger sammen.

Det er mye positivt å trekke frem om denne boken. Skal jeg likevel peke på en ting jeg savnet, var det å få eksempler på hvordan IP har blitt studert utenfor Vesten, og flere eksempler på andre teorier som har blitt oversett eller ignorert. Selv om forfatterne trekker frem blant annet feministisk teori, teoriutviklingen som ser på sammenhengen mellom raseskillet internt i USA og rasetenkningen som preget USAs handlinger i internasjonal politikk som eksempler på teorier som lenge var oversett eller ignorert, savnet jeg flere eksempler på dette. Finnes det eksempler på teorier med opphav utenfor Vesten, og som preger hvordan IP studeres $i$ andre deler av verden? For selv om forfatterne påpeker at faget IP er sterkt preget av at det har blitt utviklet i Vesten, finnes det vel eksempler på teorier med opphav andre steder?

Hva er Internasjonal Politikk gir leseren innblikk og lærdom om hva faget IP går ut på, og klarer, etter min mening, godt å forklare dette på en presis og enkel måte. For meg ga boken et fint giensyn med flere teorier og begreper, samtidig som den gjorde meg oppmerksom på hvor lett det er å gå i gamle spor og ikke tenke kritisk nok over hvorfor man tok de valgene man gjorde når det kom til enten begreper eller teorier. Carvalho og Leira sier selv at formålet med boken er å gjøre leseren i 


\section{Tora Sagård}

bedre stand til selvstendig refleksjon rundt internasjonale og globale spørsmål, noe de definitivt får til.

Dette er en bok som passer til de fleste. Enten man er student og ønsker en rask og fin innføring til faget, om man er foreldre eller besteforeldre og lurer på hva barna deres egentlig lærer på studiet, eller om man rett og slett bare er nysgjerrig på hva internasjonal politikk er. Som bokserien hevder selv: «hva er-bøkene er velskrevne introduksjoner som gir begynneren stimulerende møter med ukjente tema, og den viderekomne nye perspektiver». Jeg kan skrive under på at dette er tilfelle, og skulle selv ønske jeg hadde en slik bok da jeg studerte. 